\title{
UPAYA PENINGKATAN KOMPETENSI GURU DALAM MENYUSUN SILABUS DAN RPP MELALUI WORKSHOP DI SD NEGERI 15 JALAN API KERETA PARIAMAN
}

\author{
RATNA JUWITA \\ SD Negeri 15 Jalan Kereta Api Pariaman
}

\begin{abstract}
The research subjects were teachers of SD Negeri 15 Jalan Kereta Api. Research procedure with two cycles. Each cycle consists of two workshops, each of which includes planning, action, observation, and reflection. Data collection techniques with observation, documentation. The data analysis carried out in this study were reduction, data presentation and conclusion drawing. The results revealed that there was an increase in teachers in making learning devices in each cycle. The results of this study indicate that the implementation of the workshops can improve the ability of teachers to compile syllabus and lesson plans as well as increase the number of teachers in preparing these tools. What is expected is achieved.
\end{abstract}

Keywords: Improvement, Competence, Teacher, Syllabus, RPP.

\begin{abstract}
Abstrak: Subjek penelitian adalah Guru SD Negeri 15 Jalan Kereta Api. Prosedur penelitian dengan dua siklus. Setiap siklus terdiri dari dua kali worshop yang masingmasing siklus terdapat perencanaan, tindakan, observasi, dan refleksi. Teknik pengumpulan data dengan observasi, dokumentasi. Analisis data yang dilakukan pada penelitian ini adalah reduksi, penyajian data dan penarikan kesimpulan. Hasil penelitian mengungkapkan bahwa terdapat peningkatan guru dalam pembuatan perangkat pembelaaran pada setiap siklus. Hasil penelitian ini menunjukkan bahwa pelaksanaan worshop dapat meningkatkan kemampuan guru dalam menyusun silabus dan RPP serta peningkatan jumlah guru dalam menyusun perangkat tersebut. Apa yang di harapkan tercapai.
\end{abstract}

Kata Kunci: Peningkatan, Kompetensi, Guru, Silabus, RPP.

\section{A. Pendahuluan}

Perencanaan pembelajaran berfungsi untuk memberikan arah pelaksanaan pembelajaran sehingga menjadi terarah dan efisien. Salah satu bagian dari perencanaan pembelajaran yang sangat penting dibuat oleh guru sebagai pengarah pembelajaran adalah silabus dan Rencana Pelaksanaan Pembelajaran (RPP). Silabus ini memberikan arah tentang apa saja yang harus dicapai guna menggapai tujuan pembelajaran dan cara seperti apa yang akan digunakan. Selain itu silabus juga memuat teknik penilaian seperti apa untuk menguji sejauh mana keberhasilan pembelajaran. Didalam penyusunan silabus terdapat beberapa langkah-langkah yaitu identitas, KI dan KD, indikator, materi pokok, kegiatan pembelajaran, penilaian, alokasi waktu dan sumber.

Setelah penyusunan silabus maka di kembangkan pada rencana pelaksanaan pembelajaran (RPP). RPP adalah instrument perencanaan yang lebih spesifik dari silabus. Rencana Pelaksanaan Pembelajaran ini dibuat untuk memandu guru dalam mengajar agar tidak melebar jauh dari tujuan pembelajaran. Dengan melihat pentingnya penyusunan perangkat perencanaan pembelajaran ini, guru semestinya tidak mengajar tanpa adanya rencana. Namun sayang perencanaan pembelajaran yang mestinya dapat diukur oleh kepala sekolah ini, tidak dapat diukur oleh kepala sekolah karena hanya direncanakan dalam pikiran sang guru saja. Akibatnya kepala sekolah 
sebagai pembuat kebijakan di sekolah tidak dapat mengevaluasi kinerja guru secara akademik.

Kinerja yang dapat dilihat oleh kepala sekolah hanyalah kehadiran tatap muka, tanpa mengetahui apakah kemampuan guru dalam mengelola pembelajaran sudah sesuai dengan harapan atau belum, atau sudahkah kompetensi dasar yang harus dikuasai oleh siswa terkuasai dengan benar, serta apakah pelaksanaan yang dilakukan sesuai dengan perangkat yang di buat. Hasil pengamatan di tahun pelajaran 2019/2020 di SD Negeri 15 Jalan Kereta Api Pariaman didapatkan data sebagai berikut: 1) Hanya $60 \%$ guru yang menyusun silabus dan RPP; dan 2) Secara kualitas, silabus dan RPP yang baik baru mencapai angka 30\% dari silabus dan RPP yang dibuat oleh guru.

Untuk mengatasi permasalahan tersebut, peneliti yang berkedudukan sebagai kepala sekolah di atas merencanakan untuk melakukan penelitian dengan judul "Upaya Peningkatan Kompetensi Guru Dalam Menyusun Silabus Dan RPP Melalui Workshop di SD Negeri 15 Jalan Kereta Api Pariaman: Mudahan dengan workshop tersebut diharapkan setelah kegiatan, guru mampu menyusun silabus dan RPP yang berkualitas bisa mencapai $100 \%$. Berdasarkan latar belakang dan pembatasan masalah yang telah diuraikan di atas, maka masalah pokok dalam penelitian ini dapat dirumuskan "Apakah pelaksanaan workshop dapat meningkatkan kompetensi guru dalam menyusun silabus dan RPP ?" Tujuan penelitian ini dapat dirumuskan sesuai dengan rumusan masalah yaitu mendeskripsikan bahwa pelaksanaan workshop dapat meningkatkan kompetensi guru dalam menyusun silabus dan RPP

\section{B. Metodologi Penelitian}

Lokasi penelitian adalah di SD Negeri 15 Jalan Api Kereta Pariaman yang beralamat di jalan kereta Kecamatan Pariaman Tengah. Waktu pelaksanaan direncanakan selama tiga bulan mulai Januari - Maret 2020. Penelitian ini dilaksanakan sendiri oleh Kepala SD Negeri 15 Api Jalan Kereta Pariaman yaitu terhadap guru SD Negeri 15 Jalan Kereta Api Pariaman Penelitian ini dilakukan dengan metode penelitian tindakan sekolah yang berlangsung selama 2 siklus. Masingmasing siklus terdiri dari tahapan perencanaan, pelaksanaan, observasi dan refleksi. Metode penelitian yang dilakukan peneliti adalah dengan melaksanakan worshop. Untuk mengetahui keefektifan suatu cara dalam kegiatan peningkatan kemampuan guru perlu diadakan analisa data, pada penelitian ini mengunakan teknik analisis deskriptif kualitatif, yaitu suatu metode penelitian yang bersifat menggambarkan kenyataan atau fakta sesuai dengan data yang diperoleh dengan tujuan untuk mengetahui kompetensi guru dalam menyusun perangkat pembelajaran siabus dan RPP). Kompetensi guru dalam menyusun perangkat pembelajaran dengan cara pelaksanaan worshop dikatakan berhasil jika angkanya lebih besar atau sama dengan 75 dikatakan tidak berhasil jika angkanya kurang dari 75. Data-data yang diperlukan dalam penelitian ini diperoleh melalui observasi pengolahan cara guru menyusun perangkat pembelajaran tersebut.

\section{Hasil dan Pembahasan}

\section{Kompetensi Guru Sebelum Kegiatan Penelitian}

Pada awal tahun pelajaran 2019/2020 Semester 2, peneliti mencatat guru yang menyetorkan perangkat pembelajaran untuk ditandatangani. Hasil perhitungan perangkat pembelajaran yang dikumpulkan dapat dilihat pada table berikut: Prosentase jumlah guru yang mengumpulkan perangkat pembelajaran sebelum kegiatan adalah: 
Tabel 1 Rekap Guru Yang Menyetorkan Perangkat Pembelajaran

\begin{tabular}{|l|l|c|c|c|}
\hline No & Komponen & $\begin{array}{c}\text { Jumlah } \\
\text { seharusny } \\
\text { a }\end{array}$ & $\begin{array}{c}\text { Yang men } \\
\text { gumpulkan }\end{array}$ & $\begin{array}{l}\text { \% yang } \\
\text { mengumpulka } \\
\text { n }\end{array}$ \\
\hline 1 & Silabus & 8 & 6 & 75 \\
\hline 2 & RPP Jumlah & 8 & 6 & 75 \\
\hline \multicolumn{2}{|c|}{ J } & $\mathbf{1 0 0}$ & $\mathbf{7 5}$ & $\mathbf{7 5}$ \\
\hline
\end{tabular}

Dari table di atas jelas terlihat bahwa data dasar guru yang meyusun perangkat pembelajaran adalah sebesar $60 \%$. Dari silabus dan RPP yang terkumpul ini, kemudian penulis melakukan penelaahan terhadap kualitas dari perangkat pembelajaran yang dikumpulkan terutama pada silabus dan RPP. Data yang diperoleh dari penelaahan tersebut dapat digambarkan pada table kualitas silabus dan RPP guru SD Negeri 15 Jalan Kereta Api Pariaman pada sub berikut. Kualitas silabus dan RPP yang dibuat oleh guru SD Negeri 15 Jalan Kereta Api Pariaman secara umum dapat dikatakan kurang baik. Hal ini dikarenakan masih banyak silabus dan RPP yang masih menggunakan format lama dan terkesan tidak original (copy paste dari orang lain). Hal ini terlihat dari tidak timbulnya visi dan misi serta tujuan sekolah pada silabus dan RPP yang dibuat oleh guru.

Secara lebih jelas berikut penulis gambarkan hasil penilaian penulis terhadap kualitas silabus dan RPP 60 orang guru SD Negeri 15 Jalan Kereta Api Pariaman semester 2 tahun pelajaran 2019/2020, masih kategori cukup.

Tabel 2 Daftar Nilai Kualitas Silabus Dan RPP

\begin{tabular}{|l|l|c|c|c|c|c|}
\hline No & Indikator & Tertinggi & Terendah & Rata-rata & Jml yg baik & \% \\
\hline 1 & Silabus & 75 & 61 & 68 & 4 & 50 \\
\hline 2 & RPP & 75 & 62 & 68 & 4 & 50 \\
\hline 3 & Rerata & 75 & 61 & 68 & 4 & 50 \\
\hline
\end{tabular}

Dari table di atas, jelas terlihat bahwa kualitas silabus da RPP guru SD Negeri 15 Jalan Kereta Api Pariaman pada tahun pelajaran 2019/2020 semester 2 masih sangat rendah. Dari 10 orang guru yang silabus dan RPP-nya dianalisa oleh peneliti, hanya rata-rata $40 \%$ guru yang memiliki silabus dan RPP yang sesuai dan dinilai baik..

\section{Kompetensi Guru dalam menyusun silabus dan RPP setelah worshop siklus ke- 1}

Kuantitas Guru yang menyusun silabus dan RPP siklus ke-1. Pada rapat awal tahun pelajaran 2019/2020 semester 2, peneliti memerintahkan kepada seluruh guru untuk membuat perangkat pembelajaran. Setelah berjalan selama hampir 1 bulan, peneliti mengumumkan kepada seluruh guru bahwa pada bulan Februari 2020 akan dilakukan worshop penysunan silabus dan RPP. Pada awal semester 2 seluruh guru diminta untuk mengumpulkan perangkat pembelajaran sebelum diadakan worshop, dan sudah di analisa oleh peneliti sebagai kepala sekolah dengan hasil sudah di paparkan diatas. Pada tanggal 3 dan 4 diadakan worshop yang di pimpin oleh kepala sekolah sendiri. Nara sumber untuk pelaksanaan worshop penyusunan silabus sesuai dengan ketentuan pada kurikulum 2013 adalah kepala sekolah yang di bantu oleh pengawas binaan sekolah tersebut. Setelah dilaksanakan worshop selama 2 hari, maka seluruh guru SD Negeri 15 Jalan Kereta Pariaman di suruh kembali menyusun silabus dan RPP sesuai dengan penjelasan nara sumber, dan juga menurut Standar Isi. Seteah selesai di susun di kumpulkan kembali apa yang telah di buat oleh guru kelas seluruhnya. Kepala 
sekolah sebagai peneliti kembali menganalisa silabus dan RPP di susun oleh guru. Hasilnya adalah sebagai berikut.

Tabel 3 Rekap Perhitungan Silabus Dan RPP Pada Siklus 1

\begin{tabular}{|l|l|c|c|l|}
\hline No & Komponen & $\begin{array}{c}\text { Jumlah } \\
\text { seharusny } \\
\mathbf{a}\end{array}$ & $\begin{array}{c}\text { Yang men } \\
\text { gumpulkan }\end{array}$ & $\begin{array}{l}\text { \% yang } \\
\text { mengumpulka } \\
\text { n }\end{array}$ \\
\hline 1 & Silabus & 8 & 7 & 88 \\
\hline 2 & RPP & 8 & 7 & 88 \\
\hline \multicolumn{2}{|c|}{ Jumlah } & $\mathbf{1 0 0}$ & $\mathbf{8 8}$ & $\mathbf{8 8}$ \\
\hline
\end{tabular}

Sumber: Lembar control pengumpulan silabus dan RPP tanggal 6 Febr 2020

Dari data jumlah guru yang mengumpulkan silabus dan RPP pada awal siklus 1, dapat terlihat bahwa dengan informasi adanya worshop terhadap guru dapat meningkatkan kuantitas jumlah guru yang menyusun silabus dan RPP yang sebelumnya hanya $75 \%$, mengalami peningkatan kuantitas menjadi $88 \%$.

Kualitas silabus dan RPP setelah siklus ke-1. Sebelum melakukan worshop terhadap seluruh guru. Peneliti melakukan analisa terhadap silabus dan RPP yang dibuat oleh guru. Hasil analisis kualitas silabus dan RPP tersebut dapat terlihat pada table diatas. Setelah pelaksanaan worshop guru kembali menyusun silabus dan RPP, maka kualitas silabus dan RPP yang disusun oleh guru adalah sebagai berikut:

Tabel 4 Rekap Penilaian Silabus Dan RPP Pada Siklus 1

\begin{tabular}{|l|l|c|c|c|c|c|}
\hline No & Indikator & Tertinggi & Terendah & Jml yg baik & Jml AB & $\%$ \\
\hline 1 & Silabus & 90 & 70 & 4 & 2 & 75 \\
\hline 2 & RPP & 92 & 68 & 4 & 2 & 75 \\
\hline 3 & Rerata & 91 & 69 & 4 & 2 & 75 \\
\hline
\end{tabular}

Hasil analisa silabus dan RPP pada table diatas memperlihatkan terjadinya peningkatan kualitas silabus dan RPP. Dimana kualitas A dan B meningkat dari 40 menjadi 60. Dari sini pula terlihat bahwa jumlah guru yang mengumpulkan sampel silabus dan RPP menjadi $90 \%$.

\section{Refleksi}

Setelah dilaksanakan worshop untuk meningkatkan kemampuan guru dalam menyusun silabus dan RPP maka silabus dan RPP yang di susun guru setrlah worshop sudah ada peningkatan dalam segi kuantitas, dan dari kualitas juga ada peningkatan, tapi belum mencapai apa yang dinginkan. Dalam penelitian ini maka di lanjutkan kembali ke siklus berikutnya. Sebelum di laksanakan siklus maka diadakan perbaikan yaitu sebelum workshop ke dua di mulai, guru di berikan contoh silabus dan RPP yang sudah sesuai dengan standar isi, maka di suruh guru menyusun kembali sebelum worshop, baru lanjut ke berikutnya.

Kompetensi guru menyusun silabus dan RPP setelah siklus ke-2. Pada siklus kedua ini, penelitian dilanjutkan dengan melaksanakan worshop, yaitu tanggal 21 dan 22 Februari 2020. Worshop di mulai kembali yang di pandu oleh kepala sekolah sebagai peneliti. Peneliti mengamati apa yang di kerjakan guru. Setelah 2 hari diadakan worshop pada siklus II maka guru di suruh kembali menyusun silabus dan RPP yang di bimbing oleh kepala sekolah dan pengawas binaaa. Hasil kerja guru dalam menyusun silabus dan RPP di kumpulkan kembali untuk di analisa oleh peneliti. Yang mengumpulkan silabus dan RPP adalah sebagai berikut 
Tabel 5 Rekap Perhitungan Silabus Dan RPP Pada Siklus 1I

\begin{tabular}{|l|l|c|c|c|}
\hline No & Komponen & $\begin{array}{c}\text { Jumlah } \\
\text { seharusny } \\
\text { a }\end{array}$ & $\begin{array}{c}\text { Yang men } \\
\text { gumpulkan }\end{array}$ & $\begin{array}{l}\text { \% yang } \\
\text { mengumpulka } \\
\text { n }\end{array}$ \\
\hline 1 & Silabus & 10 & 10 & 100 \\
\hline 2 & RPP & 10 & 10 & 100 \\
\hline \multicolumn{2}{|c|}{ Jumlah } & $\mathbf{1 0 0}$ & $\mathbf{1 0}$ & $\mathbf{1 0 0}$ \\
\hline
\end{tabular}

Hasil analisa peneliti terhadap perangkat pembelajaran yang di susun sudah semua guru menyusun silabus dan RPP, dan juga sudah bagus, sesuai dengan ketentuan yang sudah di atur dalam standar isi. Hasil analisa peneliti terhadap silabus dan RPP yang disusun guru adalah sebagai berikut.

Tabel 6 Hasil Penilaian Hasil Worshop

\begin{tabular}{|l|l|c|c|c|c|c|}
\hline No & Indikator & Tertinggi & Terendah & Jml yg Baik & Jml AB & \% \\
\hline 1 & Silabus & 95 & 83 & 5 & 5 & 100 \\
\hline 2 & RPP & 95 & 85 & 6 & 4 & 100 \\
\hline 3 & Rerata & 91 & 84 & & & 100 \\
\hline
\end{tabular}

Dari hasil perhitungan pada table di atas, maka dapat ditarik sebuah kesimpulan bahwa silabus dan RPP yang dikumpulkan guru adalah bersifat original. Hal ini terlihat dengan cukup besarnya guru mampu menyusun silabus dan RPP. Hasil analisa peneliti terhadap silabus dan RPP yang disusun oleh guru sudah mencapai kategori yang dinginkan, malahan lebih dari target, sesuai dengan tabel di atas. Dari segi kuantitas 90\% guru sudah mampu menyusun silabus dan RPP, dari kualitas 90 nilai yang di peroleh. Melalui worshop ini bisa meningkatkan kompetensi guru SD Negeri 15 Jalan Kereta Api Pariaman dalam menyusun silabus dan RPP. Mudahan di masa yang akan datang jauh lebih baik lagi, amiiiiin.

\section{Pembahasan}

Dari hasil penelitian pada siklus I dan ke II maka dalam pembahasan ini di uraikan tentang worshop yang dilaksanakan untuk meningkatkan kemampuan guru dalam penyusunan perangkat pembelaaran. Terutama silabus dan RPP. Pada siklus I setelah dilaksanakan worshop oleh peneliti sebagai kepala sekolah, guru yang membuat perangkat pebelajaran belum semuanya, ada beberapa orang yang belum membuat dan mengumpulkan perangkat pembelajaran. Setelah dilakasanakan supervisi tentang pembuatan perangkat pembelajaran dan pengumpulannya maka peneliti menganalisa kenapa guru banyak yang tidak mengumpulkan perangkat pembelajaran. Yang mengumpulkan pada awalnya atau pra siklus I 60\% dan setelah pelasanaan siklus I mencapai 90\% naik sekitar 30\%, ini baru kategori AB.

Dari segi kualitas perangkat pembelajaran masih rendah yaitu mencapai $40 \%$ yang kategori B, dan selebihnya masih kategori C dan D. Karena kualitas masih rendah maka peneliti kembali melaksanakan penelitian ke siklus II. Dalam siklus II lanjutan dari siklius I, maka peneliti berpedoman ke siklus I sehingga mengadakan perbaikan dalam pelaksanaan pembimbingan guru melalui worshop, sehingga guru mampu menyusun perangkat pembelajaran dan berkualitas.

Setelah dilaksanakan worshop kembali pada siklus II ini, maka guru kembali mengumpulkan perangkat pembelajaran yang telah di revisi oleh guru sesuai dengan bimbingan dalam pelaksanaan worshop. Hasil dari segi kuantitas dalam pengumpulan perangkat pembelajaran meningkat dari siklus I yaitu menjadi $90 \%$, sedang kualitasnya mencapai $60 \%$. Pelaksanaan penelitian dengan meningkatkan kemampuan guru dalam 
menyusun RPP \& Siabus melalui worshop sangat berpengaruh, sehingga guru mampu menyusun RPP \& Silabus dengan baik sesuai dengan rambu - rambu penyusunan perangkat pembelajaran, dan kualitas sangat baik.

\section{Penutup}

Berdasarkan hasil penelitian yang terurai pada bab IV, kami dapat menyimpulkan bahwa: 1) Melalui worshop terbukti secara ilmiah dapat meningkatkan kompetensi guru dalam menyusun silabus dan RPP di SD Negeri 15 Jalan Kereta Api Pariaman. Ini terbukti dengan meningkatnya jumlah silabus guru yang baik dari $40 \%$ menjadi $60 \%$ pada siklus I setelah worshop. Selain itu jumlah RPP yang berkualitas baik juga meningkat dari $30 \%$ menjadi $60 \%$. 2) Langkah-langkah yang mengakibatkan terjadinya peningkatan kompetensi guru dalam menyusun silabus dan RPP tersebut meliputi langkah-langkah sebagai berikut: Melaksanakan worshop penyusunan silabus dan RPP, Pelaksanaan worshop selama 4 hari, dimana setiap guru diminta menyusun silabus dan RPP-nya setelah pelaksanaan worshop setiap siklus, Masing-masing siklus di laksanakan worshop selama 2 hari, dan 4) Untuk melihat silabus dan RPP yang disusun guru, kepala sekolah melakukan analisa terhadap silabus yang telah di susun. Hal ini dilakukan untuk men ingkatkan kemampuan guru dalam penyusunan silabus dan RPP. 3) Peningkatan kompetensi guru dalam menyusun silabus dan RPP yang baik meningkat sebesar $60 \%$.

\section{Daftar Pustaka}

Anwar, Moch. Idochi. 2004. Administrasi Pendidikan dan Manajemen Biaya Pendidikan. Bandung: Alfabeta

Badan Standar Nasional Pendidikan dan Direktorat Tenaga Kependidikan, 2006, Naskah Akademik Standar Kependidikan dan Kompetensi Tim sekolah,

Badudu.J.S, 1988, Kamus Besar Bahasa Indonesia, Jakarta: Gramedia

Buku Kita, 2007, Standar Kompetensi Tim sekolah, Jakarta: Pustaka Yustisia

Depdiknas, 2003, Manajemen Berbasis Sekolah Direktorat Jendral Pendidikan

Dasar dan Menengah: Direktorat Tenaga Kependidikan.

Harahap, Baharuddin. 1983. Supervisi Pendidikan yang Dilaksanakan oleh Guru, Kepala Sekolah, Penilik dan Pengawas Sekolah. Jakarta: Damai Jaya

Majid, Abdul. 2005. Perencanaan Pembelajaran: Mengembangkan Standar Kompetensi Guru. Bandung: PT Remaja Rosdakarya.

Muhaimin (2004). Paradigma Pendidikan Islam. Bandung: PT Remaja Rosdakarya.

Mulyasa, E., 2003. Kurikulum Berbasis Kompetensi: Konsep, Karakteristik, dan Implementasi. Bandung: PT Remaja Rosdakarya

Sahertian, Piet A. 2000. Konsep-Konsep dan Teknik Supervisi Pendidikan Dalam Rangka Pengembangan Sumber Daya Manusia. Jakarta: Rineka Cipta.

Surya, Muhammad. 2003. Psikologi Pembelajaran dan Pengajaran. Bandung: Yayasan Bhakti Winaya

Suryasubrata.1997. Proses Belajar Mengajar di Sekolah. Jakarta: Rineka Cipta.

Usman, Moh. Uzer. 1994. Menjadi Guru Profesional. Bandung: PT Remaja Rosdakarya.

Wahidin; 13 Faktor untuk menjadi Kepala Sekolah Yang Efektif, 2008

Wardani, IGK. 1996. Alat Penilaian Kemampuan Guru (APKG). Jakarta: Dirjen Dikti. 